\title{
CONSTRUCTION OF OPTIMUM PORTFOLIO WITH BSE LISTED COMPANIES
}

\begin{tabular}{|c|c|}
\hline $\begin{array}{c}\text { KIRAN } \\
2^{\text {nd }} \text { Year M.Com, Alva's College, } \\
\text { Moodbidri. } \\
\text { Email:Kirandevadiga712@gmail.com }\end{array}$ & $\begin{array}{c}\text { Dr.Kushalappa.S } \\
\text { Assistant Professor, Department of } \\
\text { MBA, AIET, Mijar, } \\
\text { Moodbidri.574225, Mob: 9686324188 } \\
\text { Email:kushalkayarthadka@ gmail.com }\end{array}$ \\
\hline
\end{tabular}

\section{ABSTRACT}

Modern portfolio theory has one central theme: "In constructing their portfolios investors need to look at the expected return of each investment in relation to the impact that it has on the risk of the overall portfolio". Portfolio management concerns the constructions and maintenance of a collection of investment. It is investment of funds in different securities in which the total risk of the portfolio is minimized, while expecting maximum return from it. It primarily involves reducing risk rather than increasing return. Return is obviously important though, and the ultimate objective of portfolio manager is to achieve a chosen level of return by incurring the least possible risk. The paper aims at constructing an optimal portfolio by applying Sharpe's single Index model of capital asset pricing, this model helps an investor to select the best securities to be included in an optimal portfolio and the weights of investment in each security. The main objective of the study is to construct an optimal portfolio of 30 Index Stocks of Bombay Stock Exchange. The entire study is based on secondary data extracted from websites like Bombay Stock Exchange (BSE), Reserve Bank of India (RBI), books and journals. The sample size 30 companies listed on BSE. The analysis is based on stock returns of 30 companies for one year from $1^{\text {st }}$ April 2013 to $31^{\text {st }}$ March 2014.

KEY WORDS:Sharpe's single index model, Sharpe ratio, optimal portfolio, cut-off rate Portfolio, optimal portfolio, market risk, unsystematic risk, variance,

\section{INTRODUCTION}

Portfolio is the collection of financial or real assets such as equity shares, debentures, bonds, treasury bills and property etc. portfolio is a combination of assets or it consists of collection of securities. These holdings are the result of individual preferences, decisions of the holders regarding risk, return and a most of other considerations. Modern portfolio theory has one central theme: "In constructing their portfolios investors need to look at the expected return of each investment in relation to the impact that it has on the risk of the overall portfolio". Portfolio management concerns the constructions and maintenance of a collection of investment. It is investment of funds in different securities in which the total risk of the portfolio is minimized, while expecting maximum return from it. It primarily involves reducing risk rather than increasing return. Return is obviously important though, and the ultimate objective of portfolio manager is to achieve a chosen level of return by incurring the least possible risk.The paper aims at constructing an optimal portfolio 
by applying Sharpe's single Index model of capital asset pricing, this model helps an investor to select the best securities to be included in an optimal portfolio and the weights of investment in each security. The main objective of the study is to construct an optimal portfolio of 30 Index Stocks of Bombay Stock Exchange. The entire study is based on secondary data extracted from websites like Bombay Stock Exchange (BSE), Reserve Bank of India (RBI), books and journals. The sample size 30 companies listed on BSE. The analysis is based on stock returns of 30 companies for one year from $1^{\text {st }}$ April 2013 to $31^{\text {st }}$ March 2014.

\section{OBJECTIVES OF THE STUDY:}

The main objective of the study is to construct an optimal portfolio of BSE 30 stocks. In order to achieve the main objective, the following subsidiary objectives have been drawn:

- To analyze the performance of sample companies based on their return, systematic risk, unsystematic risk

- To find out the excess return to beta ratio.

- To identify the stocks supposed to be included in the optimum portfolio
- To find out the proportion of investment under each security included in the optimum portfolio

\section{METHODOLOGY:}

The entire study is based on secondary data extracted from websites like Bombay Stock Exchange (BSE), Reserve Bank of India (RBI), books and journals. The sample size is 30 companies listed on BSE Sensex. The analysis is based on stock returns of 30 companies for oneyear from April 12013 to $31^{\text {st }}$ March 2014.

\section{SCOPE OF THE STUDY:}

The study is all about construction of an optimal portfolio with stocks of BSE 30 companies. Thirty companies have been selected for the purpose construction of an optimal portfolio. The study covers a period of one year from April $1^{\text {st }} 2013$ to $31^{\text {st }}$ March 2014.

\section{$\begin{array}{lll}\text { DATA ANALYSIS AND } & \text { ANA }\end{array}$ INTERPRETATION}

Here an attempt is made by the researchers to analyse the data collected from secondary sources. It is clear from Table 1 that among the stocks under study, Hindalco has highest average returns with $0.206799 \%$ return and NTPC obtained the lowest returns with $-0.05247 \%$ return. In terms of systematic risk, Cipla has the lowest risk and Axis bank has the highest risk. Reliance has the lowest unsystematic 
risk and sun pharma has the highest unsystematic risk compared to other stocks under study. Cipla has the lowest total risk and sun pharma has the highest total risk compared to other stocks under study.

As per Table 2 it is crystal clear that Dr Reddy's stock has the highest (0.248313) excess return-beta ratio and NTPC has the lowest (-0.10892) excess return-beta ratio.

Table 3 shows that the securities supposed to be included in the portfolio. The cut-off point is 0.11198455 and it is obtained for

Table 1: Ranking of the stocks of sample manufacturing companies based on returns, systematic risk, unsystematic

\begin{tabular}{|l|l|c|c|c|c|c|c|}
\hline Sl. & Stocks & $\begin{array}{c}\text { Daily } \\
\text { No }\end{array}$ & Rank & Systematic \\
returns (\%) & Rank & Unsystematic & Rank \\
risk & & \\
\hline 1 & Dr. Reddy & 0.206799 & 1 & 1.797788 & 22 & 4.93921 & 26 \\
\hline 2 & TCS & 0.192077 & 2 & 0.986917 & 13 & 3.102061 & 19 \\
\hline 3 & Hero Motors & 0.184957 & 3 & 1.392179 & 17 & 3.306045 & 22 \\
\hline 4 & Maruti Suzuki & 0.171369 & 4 & 0.680216 & 9 & 2.2254 & 9 \\
\hline 5 & Hindalco & 0.146861 & 5 & 0.292013 & 2 & 2.613603 & 16 \\
\hline 6 & Tata Motors & 0.140119 & 6 & 0.376661 & 3 & 2.544907 & 14 \\
\hline 7 & HUL & 0.12674 & 7 & 1.653153 & 20 & 6.509378 & 28 \\
\hline 8 & Wipro & 0.12151 & 8 & 1.975426 & 25 & 4.459807 & 25 \\
\hline 9 & SesaSterlite & 0.115384 & 9 & 0.494934 & 5 & 3.063706 & 17 \\
\hline 10 & Tata Stel & 0.109427 & 10 & 1.060738 & 14 & 2.490128 & 13 \\
\hline 11 & GAIL & 0.093176 & 11 & 2.980922 & 29 & 2.241758 & 10 \\
\hline 12 & Infosys & 0.089501 & 12 & 1.982849 & 26 & 1.386408 & 2 \\
\hline 13 & Bajaj Motors & 0.084969 & 13 & 1.481221 & 18 & 1.357339 & 1 \\
\hline 14 & Reliance & 0.078435 & 14 & 3.444405 & 30 & 1.778274 & 6 \\
\hline
\end{tabular}

the fourth stock, which is ranked in terms of excess return to beta ratio. As per the rule, the stocks above $\mathrm{C}^{*}$ can be included in the portfolio.

Table 4 shows the proportion of investment to be made in each stock. It is clear from the table that highest proportion of investment is to be made (i.e., $0.228053 \%$ ) in Hero motorcorp stock and lowest investment is to be made (i. $0.074597 \%$ ) in Hindalco stock. 
Asia Pacific Journals

\begin{tabular}{|l|l|c|c|c|c|c|c|}
\hline 15 & M\&M & 0.075953 & 15 & 0.596857 & 7 & 2.028403 & 8 \\
\hline 16 & HDFC Bank & 0.075885 & 16 & 2.312397 & 28 & 6.409725 & 27 \\
\hline 17 & ITC & 0.072917 & 17 & 0.78672 & 11 & 1.632407 & 4 \\
\hline 18 & ICICI & 0.070865 & 18 & 0.915661 & 12 & 2.287438 & 11 \\
\hline 19 & BHEL & 0.069711 & 19 & 1.060738 & 15 & 1.625308 & 3 \\
\hline 20 & Axis Bank & 0.06559 & 20 & 0.381907 & 4 & 3.860593 & 23 \\
\hline 21 & Bharati Airtel & 0.057572 & 21 & 1.793995 & 21 & 3.118367 & 20 \\
\hline 22 & HDFC & 0.047695 & 22 & 2.06195 & 27 & 1.806092 & 7 \\
\hline 23 & ONGC & 0.035382 & 23 & 1.875166 & 23 & 2.560809 & 15 \\
\hline 24 & L\&T & 0.012231 & 24 & 1.894098 & 24 & 6.78766 & 29 \\
\hline 25 & Cipla & 0.009508 & 25 & 0.259163 & 1 & 1.770753 & 5 \\
\hline 26 & SBI & -0.00411 & 26 & 0.566968 & 6 & 3.277208 & 21 \\
\hline 27 & Coal India & -0.01437 & 27 & 1.543525 & 19 & 2.474263 & 12 \\
\hline 28 & Tata Power & -0.02158 & 28 & 1.182864 & 16 & 4.162515 & 24 \\
\hline 29 & Sun Pharma & -0.04936 & 29 & 0.726749 & 10 & 12.33352 & 30 \\
\hline 30 & NTPC & -0.05247 & 30 & 0.608245 & 8 & 3.074582 & 18 \\
\hline
\end{tabular}

Source: Authors compilation

Table 2: Excess return to beta ratio and cut-off point calculations for manufacturing companiesunderstudy

\begin{tabular}{|l|l|c|c|}
\hline \multicolumn{1}{|c|}{ SI no } & \multicolumn{1}{|c|}{ Stocks } & $\mathbf{R}_{\mathbf{i}}-\mathbf{R}_{\mathbf{f}} / \boldsymbol{\beta}_{\mathbf{i}}$ & Rank \\
\hline 1 & Dr. Reddy & 0.248313 & 1 \\
\hline 2 & TCS & 0.20656 & 3 \\
\hline 3 & Hero Motors & 0.195362 & 4 \\
\hline 4 & Maruti Suzuki & 0.185105 & 5 \\
\hline 5 & Hindalco & 0.149218 & 6 \\
\hline 6 & Tata Motors & 0.149218 & 7 \\
\hline 7 & HUL & 0.141546 & 9 \\
\hline 8 & Wipro & 0.090329 & 10 \\
\hline 9 & SesaSterlite & 0.087158 & 0.075642 \\
\hline 10 & Tata Stel & & \\
\hline
\end{tabular}


Asia Pacific Journals

\begin{tabular}{|c|c|c|c|}
\hline 11 & GAIL & 0.072788 & 11 \\
\hline 12 & Infosys & 0.07256 & 12 \\
\hline 13 & Bajaj Motors & 0.059636 & 13 \\
\hline 14 & Reliance & 0.054349 & 14 \\
\hline 15 & $\mathrm{M} \& \mathrm{M}$ & 0.05292 & 15 \\
\hline 16 & HDFC Bank & 0.050511 & 16 \\
\hline 17 & ITC & 0.047937 & 17 \\
\hline 18 & ICICI & 0.043536 & 18 \\
\hline 19 & BHEL & 0.03693 & 19 \\
\hline 20 & Axis Bank & 0.03177 & 20 \\
\hline 21 & Bharati Airtel & 0.026898 & 21 \\
\hline 22 & HDFC & 0.017528 & 22 \\
\hline 23 & ONGC & 0.008495 & 23 \\
\hline 24 & L\&T & -0.01004 & 24 \\
\hline 25 & Cipla & -0.03302 & 25 \\
\hline 26 & SBI & -0.03466 & 26 \\
\hline 27 & Coal India & -0.04221 & 27 \\
\hline 28 & Tata Power & -0.04688 & 28 \\
\hline 29 & Sun Pharma & -0.09563 & 29 \\
\hline 30 & NTPC & -0.10892 & 30 \\
\hline
\end{tabular}

\section{Source: Authors compilation}

Table 3: $C_{i}$ values for sample stocks

\begin{tabular}{|c|c|c|c|c|c|c|c|}
\hline $\begin{array}{l}\text { Sl. } \\
\text { No }\end{array}$ & Stocks & $\frac{\left(\boldsymbol{R}_{i}-\boldsymbol{R}_{\boldsymbol{f}}\right) \boldsymbol{\beta}_{i}}{\boldsymbol{\sigma}_{e i}^{2}}$ & $\sigma_{m}^{2} \sum_{I=1}^{N} \frac{\left(R_{i}-I\right.}{\sigma_{e}^{2}}$ & $\frac{\beta_{i}^{2}}{\sigma_{e i}^{2}}$ & $\sum_{i=1}^{N} \frac{\beta_{i}^{2}}{\sigma_{e i}^{2}}$ & $\begin{array}{l}1 \\
+\sigma_{m}^{2} \sum_{i=1}^{N} \frac{\beta_{i}^{2}}{\sigma_{e i}^{2}}\end{array}$ & $\mathrm{CI}$ \\
\hline 1 & Dr. Reddy & 0.02295716 & 0.02295716 & 0.092453 & 0.092453 & 1.11172812 & 0.0249553 \\
\hline 2 & TCS & 0.02529769 & 0.04825485 & 0.122471 & 0.214924 & 1.25973374 & 0.0462920 \\
\hline 3 & Hero Motors & 0.0494122 & 0.09766705 & 0.252927 & 0.467851 & 1.56539362 & 0.0753994 \\
\hline 4 & Maruti Suzuki & 0.04873081 & 0.14639786 & 0.263261 & 0.731111 & $1.88354238 \backslash$ & 0.0939297 \\
\hline 5 & Hindalco & 0.04494275 & 0.19134061 & 0.301188 & 1.032299 & 2.24752534 & 0.1028836 \\
\hline
\end{tabular}


Asia Pacific Journals

\begin{tabular}{|c|c|c|c|c|c|c|c|}
\hline 6 & Tata Motors & 0.05199516 & 0.24333577 & 0.348452 & 1.380751 & 2.66862632 & 0.1101950 \\
\hline 7 & HUL & 0.01892143 & 0.2622572 & 0.133677 & 1.514428 & 2.83017381 & $\begin{array}{c}0.111984 \\
C^{*}\end{array}$ \\
\hline 8 & Wipro & 0.0318399 & 0.2940971 & 0.352486 & 1.866914 & 3.25615088 & 0.109151 \\
\hline 9 & SesaSterlite & 0.01831636 & 0.31241346 & 0.21015 & 2.077064 & 3.51011575 & 0.107560 \\
\hline 10 & Tata Stel & 0.02772463 & 0.34013809 & 0.366523 & 2.443587 & 3.95305558 & 0.103984 \\
\hline 11 & GAIL & 0.0177228 & 0.3578609 & 0.243485 & 2.687072 & 4.24730524 & 0.101823 \\
\hline 12 & Infosys & 0.00593959 & 0.36380048 & 0.081858 & 2.76893 & 4.34622958 & 0.101157 \\
\hline 13 & Bajaj Motors & 0.0237825 & 0.38758298 & 0.398793 & 3.167723 & 4.82816831 & 0.097012 \\
\hline 14 & Reliance & 0.04907675 & 0.43665973 & 0.903 & 4.070724 & 5.91943716 & 0.0891469 \\
\hline 15 & $\mathrm{M} \& \mathrm{M}$ & 0.01752923 & 0.45418896 & 0.331239 & 4.401963 & 6.31973706 & 0.0868523 \\
\hline 16 & HDFC Bank & 0.05977841 & 0.51396736 & 1.183463 & 5.585426 & 7.74994261 & 0.0801458 \\
\hline 17 & ITC & 0.02588802 & 0.53985538 & 0.540043 & 6.125469 & 8.40258066 & 0.0776441 \\
\hline 18 & ICICI & 0.04790374 & 0.58775913 & 1.100318 & 7.225787 & 9.73230600 & 0.0729839 \\
\hline 19 & BHEL & 0.01102458 & 0.5987837 & 0.298524 & 7.524311 & 10.0930697 & 0.0716952 \\
\hline 20 & Axis Bank & 0.05091945 & 0.64970315 & 1.602772 & 9.127083 & 12.0300071 & 0.0652668 \\
\hline 21 & Bharati Airtel & 0.01280456 & 0.66250771 & 0.476047 & 9.60313 & 12.6053066 & 0.0635157 \\
\hline 22 & HDFC & 0.01655834 & 0.67906605 & 0.944701 & 10.54783 & 13.7469705 & 0.0596964 \\
\hline 23 & ONGC & 0.00514756 & 0.68421361 & 0.605925 & 11.15376 & 14.4792257 & 0.0571071 \\
\hline 24 & L\&T & -0.0023183 & 0.6818953 & 0.230908 & 11.38466 & 14.7582759 & 0.0558374 \\
\hline 25 & Cipla & -0.0039992 & 0.67789606 & 0.121108 & 11.50577 & 14.9046335 & 0.0549649 \\
\hline 26 & SBI & -0.0178904 & 0.6600057 & 0.516207 & 12.02198 & 15.5284656 & 0.0513644 \\
\hline 27 & Coal India & -0.006043 & 0.65396269 & 0.143156 & 12.16514 & 15.7014689 & 0.0503334 \\
\hline 28 & Tata Power & -0.0110228 & 0.64293988 & 0.235145 & 12.40028 & 15.9856393 & 0.0486053 \\
\hline 29 & Sun Pharma & -0.004663 & 0.63827693 & 0.048759 & 12.44904 & 16.0445640 & 0.0480756 \\
\hline 30 & NTPC & -0.0178301 & 0.62044679 & 0.1637 & 12.61274 & 16.2423943 & 0.0461634 \\
\hline
\end{tabular}

Source: Authors compilation

Table 4: Proportion of investment in each stock
Sl. no
Stock
Proportion of investment 


\begin{tabular}{|l|l|c|}
\hline 1 & Dr. Reddy & 0.208028 \\
\hline 2 & TCS & 0.168328 \\
\hline 3 & HR Motors & 0.228053 \\
\hline 4 & Maruthi Suzuki & 0.172822 \\
\hline 5 & Hindalco & 0.074597 \\
\hline 6 & Tata motors & 0.098071 \\
\hline 7 & HUL & 0.050099 \\
\hline \multicolumn{2}{|l|}{ Source: Authors compilation } \\
FINDINGS OF THE STUDY
\end{tabular}

- It is found in the study that among the stocks under study, Hindalco stockhas highest average daily

returns and NTPC has the lowest average daily returns. Therefore comparatively, the most profitable stock is Hindalco.

- It is clear from the study that Ciplastock has the lowest systematic risk and Axis bankstock has the highest systematic risk compared to other stocks under study.

- It is revealed in the study that Reliance has the lowest unsystematic risk and sun Parma has the highest unsystematic risk compared to other stocks under study.

- As per study it is crystal clear that Dr .Reddysstock has the highest (0.248313)excess return-beta ratio
- It is found in the study that the cutoff point is 0.11198455 and it is obtained for the seventh ranked stock.

- The study shows the fact that highest proportion of investment is to be made0.228053 in Hero motorcorpstock and lowest investment is to be made (i.e., $5.6421 \%$ ) in HUL stock to construct the optimal portfolio.

\section{CONCLUSION:}

Sharpe's model is a scientific technique which can be used to construct the optimal portfolio. In this study out of thirty stocks selected for the study, only seven stocks are suitable to construct the optimal portfolio. The stocks supposed to be included for the constructions of optimal portfolio are; Dr Reddy's, TCS,HeroMotorCorp,MarutiSuzukiHi ndalcoTata motor HUL.The investor 
has to decide about the proportion of investment in each security as found in the study so as to make the investment more scientific. Finally, it can be concluded that present study will help the investors to create optimal portfolio and also help the investors as a guiding record in future.

\section{BIBLIOGRAPHY:}

- Balla V. K. (2002), Portfolio Analysis and Management, Sulthan Chand and Co. Ltd., New Delhi.

- BhatSudhindra (2008), Security Analysis and Portfolio Management, Excel Books, New Delhi.

- Booie.Zvi, Kane Alex and et.al.(2006), Investments, $\quad 6^{\text {th }}$ edition, Tata McGraw Hill, New Delhi.

- Chandra Prasanna (2008), Investment Analysis and Portfolio Management, $3^{\text {rd }}$ edition, Tata McGraw Hill, New Dehi.

- Fisher. E. Donald and Jordan. J. Ronald (2006), Security Analysis and Portfolio Management, Pearson Prentice Hall.

- Kevin. S (2008), Portfolio Management, $2^{\text {rd }}$ edition, PHI Learning Pvt. Ltd, New Delhi. 